\title{
An Experimental Examination on Mechanical and Durability Properties of Cement Replacing with Marble Powder
}

\author{
S.Suresh, J.Revathi
}

\begin{abstract}
Leaving the waste products straight to the environment directly can cause environmental issues. Waste can be used as a mixture to create fresh products or can be used as admixtures .In order to make more efficient use of natural assets and protect the environment from waste deposits an inert material which is procured as an industrial by-product during sawing, grinding, and polishing of marble. These wastes can be used as concrete constituents by partly replacing the cement making it cost-effective. The main objective of this research is to examine whether there is any possibility of utilizing marble powder in concrete production or not. This research involves concrete $m 20$ mixture by replacing cement with marble powder in different proportions $(0 \%, 5 \%, 10 \% \& 15 \%)$ by weight to determine the optimum proportion of replacement. The properties of concrete such as compressive strength, flexural strength and modulus of elasticity were determined at age of 7 and 28 days. The durability characteristics of concrete with cement partially replaced by waste Marble powders were also evaluated.
\end{abstract}

Keywords: Concrete, Durability, Mechanical Properties, Normal strength concrete Waste Marble Powder.

\section{INTRODUCTION}

The advancement of concrete technology can reduce the consumption of natural resources and energy sources and lessen the burden of pollutants on environment. Presently large amounts of marble dust are generated in natural stone processing plants with an important impact on environment and humans. This project describes the feasibility of using the marble sludge dust in concrete production as partial replacement of cement. In India, the marble and granite stone processing is one of the most thriving industry the effects if varying marble dust contents on the physical and mechanical properties of fresh and hardened concrete have been investigated Marble waste are dumped in any nearby pit or vacant space near the marble processing industries, although notified area have been marked for dumping the same. This causes environmental problems and also affects the ground water .The environmental problem attributed by

Waste marble powder imposes threat to ecosystem, physical, chemical and biological components of environment. The durability as well as workability has increased to large extent by use of marble dust as replacement of fine aggregate and coarse aggregate. The effect on properties of concrete were

\footnotetext{
Revised Manuscript Received on December 30, 2019.

* Correspondence Author

Dr. S. Suresh*, Professor, Department of Civil Engineering, Sona College of Technology, Salem, Tamilnadu. Email: sansuresh86@yahoo.co.in

J. Revathi, Research scholar, Anna University, Chennai. Email: er_revas05@yahoo.co.in
}

investigated and concluded that optimum percentage for replacement of sand with marble powder in concrete is almost $50 \%$.On the other hand, the effect of using marble powder and granules as constituents of fines in mortar or concrete by partially reducing quantities of cement as well as other conventional fines has been found better in terms of the relative workability and compressive as well as flexural strengths. The results of the laboratory work showed that replacement of cement with MDP up to $10 \%$ favors compressive strength, and up to $15 \%$ favors split tensile strength \& flexural strength of concrete. Ali Aliabdo et al studied the effect of replacement of cement and sand by Marble powder. The authors investigated the properties of cement modified with marble dust and that of concrete containing marble dust as a cement replacement and as a sand replacement (Cement addition). Use of marble dust in concrete production as cement replacement or as sand replacement (cement addition) enhanced both the mechanical and physical properties of concrete especially with lower water cement ratio.

\section{EXPERIMENTAL PROGRAMME}

\section{A. Cement}

OPC of 53 grades was used for this study. The cement used for all the tests is from same batch. The various properties of cement were obtained according to IS: 455-1989 and IS: 12269-1987

\section{B. Fine Aggregate}

Natural River sand was used as fine aggregate The fine aggregate was tested for various properties such as specific gravity, sieve analysis and fineness modulus according to IS $2386-1963$

\section{Coarse Aggregate}

Crushed angular granite was used as coarse aggregate. The maximum size used was $20 \mathrm{~mm}$ sieve with a specific gravity of 2.77 .

\section{Marble powder}

Waste Marble powder was collected from the local market at Pondicherry. It passed through 90 micron before mixing in concrete. Tests were carried out in order to find out the properties of Waste Marble Powder. The Specific gravity of marble powder used was 2.46 .

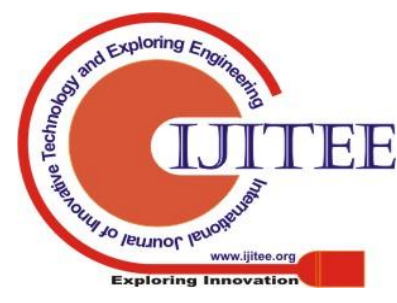




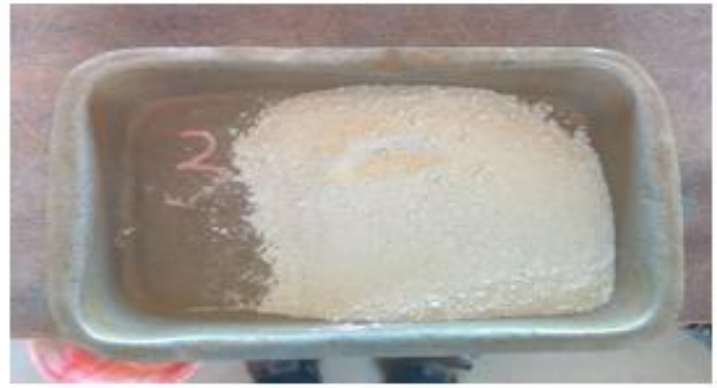

Fig 1. Marble Powder

\section{E. Water}

Water used for mixing and curing was fresh potable water conforming to IS: 3025 - 1964 part 22, part 23 and IS: $456-$ 2000 .

\section{RESULT AND DISCUSSION}

\section{A. Effect of Marble Powder on Compressive Strength:}

The compressive strength of all the test specimens are presented in Table I. A compressive strength of $24.18 \mathrm{MPa}$, 27.4 MPa, 29.8 MPa and 21.52 MPa was obtained for the specimens NSC $0 \%$, NSC $5 \%$, NSC $10 \%$ and NSC15\%.The specimen NSC $5 \%$ exhibits an increase $13.31 \%$ in compressive strength when compared to control specimen NSC $0 \%$.The specimen NSC $10 \%$ exhibits an increase of $23.24 \%$ in compressive strength when compared to control specimen (NSC $0 \%$ ). The specimen NSC $15 \%$ exhibits a decrease of $11 \%$ in compressive strength when `compared to control specimen (NSC $0 \%$ ). The experimental results show that replacement cement with Marble Powder $5 \%$ and $10 \%$ in concrete improves its compressive strength and replacement of cement Marble Powder $15 \%$ in concrete reduces its compressive strength. The graphical representations of compressive strength are shown in Fig. 2.

Table I Compressive Strength of Test Specimen

\begin{tabular}{|c|c|c|c|c|}
\hline S.NO & $\begin{array}{c}\text { Test } \\
\text { Specimen }\end{array}$ & $\begin{array}{c}\text { Marble } \\
\text { powder } \\
\text { dosage }\end{array}$ & \multicolumn{2}{|c|}{$\begin{array}{c}\text { Average flexural } \\
\text { Strength } \\
(\text { Nlmm }\end{array}$} \\
\cline { 4 - 5 } & & & 7 Days & 28 days \\
\hline 1 & NSC 0\% & 0 & 3.16 & 4.88 \\
\hline 2 & NSC 5\% & 5 & 3.72 & 5.27 \\
\hline 3 & NSC 10\% & 10 & 3.97 & 5.75 \\
\hline 4 & NSC 20\% & 15 & 4.25 & 4.67 \\
\hline
\end{tabular}

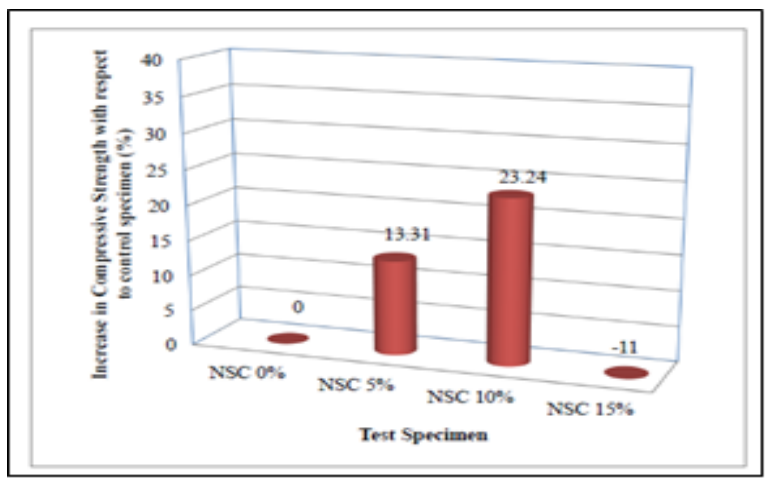

Fig 2 Compressive strength of test Specimen
The flexural strength of all the test specimens is presented in Table 2. A flexural strength of 4.88 MPa, 5.27 MPa, 5.75 $\mathrm{MPa}$ and 4.67 MPa was obtained for the specimens NSC $0 \%$, NSC $5 \%$, NSC $10 \%$ and NSC $15 \%$. The specimen NSC $5 \%$ exhibits an increase of $7.99 \%$ in flexural strength when compared to control specimen NSC $0 \%$. The specimen NSC $10 \%$ exhibits an increase of $17.82 \%$ in flexural strength when compared to control specimen NSC $0 \%$. The specimen NSC $15 \%$ exhibits a decrease of $4.3 \%$ in flexural strength when compared to control specimen NSC $0 \%$. The experimental results show that replacement of cement with marble powder $5 \%$ and $10 \%$ in concrete improves its flexural strength and replacement of cement with marble powder $15 \%$ reduces its flexural strength.

Table II Flexural Strength of Test Specimens

\begin{tabular}{|c|c|c|c|c|}
\hline S.NO & \multirow{2}{*}{$\begin{array}{c}\text { Test } \\
\text { Specimen }\end{array}$} & $\begin{array}{c}\text { Marble } \\
\text { Powder } \\
\text { dosage }\end{array}$ & \multicolumn{2}{|c|}{$\begin{array}{c}\text { Average } \\
\text { Compressive } \\
\text { Strength }(\text { NImm }\end{array}$} \\
\cline { 3 - 5 } & & & 7 Days & 28 Days \\
\hline 1 & NSC 0\% & 0 & 16.51 & 24.18 \\
\hline 2 & NSC 5\% & 5 & 24.99 & 27.4 \\
\hline 3 & NSC 10\% & 10 & 26.52 & 29.28 \\
\hline 4 & NSC 20\% & 15 & 15.21 & 21.52 \\
\hline
\end{tabular}

The graphical representations of flexural strength are shown in Fig.3. The test results on the various mechanical properties clearly indicate that the addition of marble powder at optimum dosage of $10 \%$ resulted in increased performance and thereafter the strength was pronouncedly decreased at higher dosages. This is due to reduction in cementing material, $\mathrm{C}_{3} \mathrm{~S}$ and $\mathrm{C}_{2} \mathrm{~S}$, which is responsible for concrete strength

\section{Effect of Marble Powder on Elasticity Modulus}

The modulus of elasticity all the test specimens are presented in Table 3 . Elasticity modulus of $21.23 \mathrm{GPa}, 24.42$ $\mathrm{GPa}, 26.26 \mathrm{GPa}$ and $19.23 \mathrm{GPa}$ was obtained for the specimens NSC $0 \%$, NSC $5 \%$, NSC $10 \%$ and NSC $15 \%$.

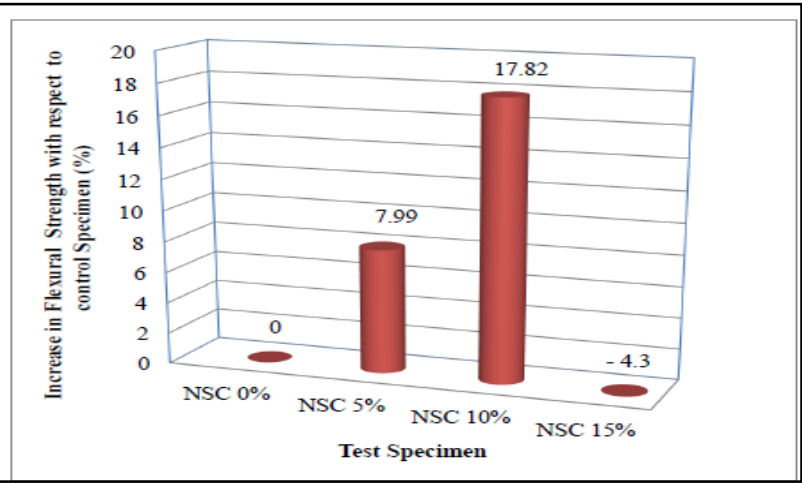

Fig 3. Flexural Strength of Test specimen

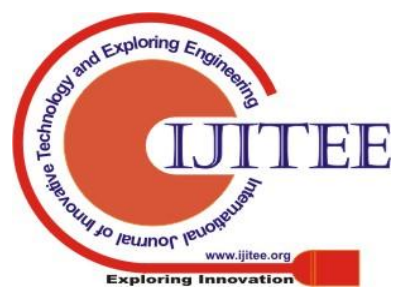


The specimen NSC $5 \%$ exhibits an increase of $15.02 \%$ in modulus of elasticity when compared to control specimen NSC $0 \%$. The specimen NSC $10 \%$ exhibits an increase of $23.55 \%$ in modulus of elasticity when compared to control specimen NSC $0 \%$.The specimen NSC $15 \%$ exhibits a decrease of $9.42 \%$ in modulus of elasticity when compared to control specimen NSC $0 \%$.The experimental results show that replacement of cement with Marble Powder 5\%, $10 \%$ in concrete improves its elasticity modulus and replacement of cement with Marble Powder $15 \%$ in concrete reduces its elasticity modulus. Normally the elasticity modulus of concrete is directly proportional to the compressive strength, so the increase of compressive strength resulting in increased elasticity modulus. The stress-strain curve is presented in Fig. 4.

Table III Modulus of Elasticity of Test specimens

\begin{tabular}{|c|c|c|c|}
\hline S.NO & $\begin{array}{c}\text { Test } \\
\text { Specimen }\end{array}$ & $\begin{array}{c}\text { Marble } \\
\text { powder } \\
\text { dosage }\end{array}$ & $\begin{array}{c}\text { Average } \\
\text { flexural } \\
\text { Strength } \\
(\text { Nlmm }\end{array}$ \\
\cline { 3 - 4 } & & 28 days \\
\hline 1 & NSC 0\% & 0 & 21.23 \\
\hline 2 & NSC 5\% & 5 & 24.42 \\
\hline 3 & NSC 10\% & 10 & 26.26 \\
\hline 4 & NSC 20\% & 15 & 19.23 \\
\hline
\end{tabular}

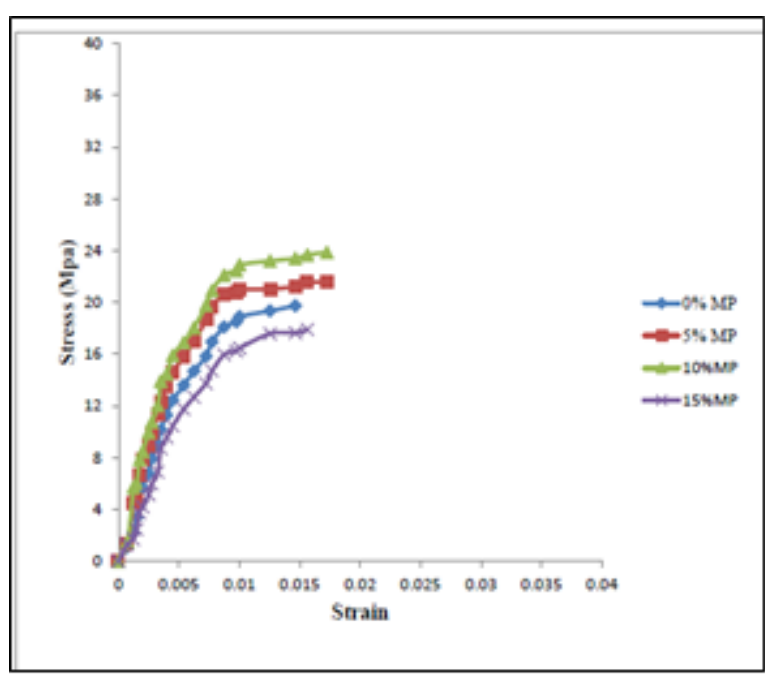

Fig 4. Stress -Strain Curve

\section{Effect of Marble Powder on Chloride Penetration}

The chloride penetration on conventional and marble powder at 28 days is given in Table IV. It was observed that with the addition of marble powder $(10 \%)$ there is a significant decrease in chloride penetration which shows that the marble powder is densely packed. The test results obtained are presented in Table IV.

Table IV Rapid chloride penetration test

\begin{tabular}{|c|c|c|c|}
\hline $\begin{array}{c}\text { Nature of } \\
\text { Specimen }\end{array}$ & $\begin{array}{c}\text { Volume } \\
\text { fraction (\%) }\end{array}$ & $\begin{array}{c}\text { Charge } \\
\text { Passed 'Q' in } \\
\text { coulombs }\end{array}$ & \\
\hline Cylinder & $0 \%$ & 1254 & Low Penetration \\
\hline
\end{tabular}

\begin{tabular}{|c|c|c|c|}
\hline & $5 \%$ & 1527 & Low Penetration \\
\cline { 2 - 4 } & $10 \%$ & 986 & $\begin{array}{c}\text { Very Low } \\
\text { Penetration }\end{array}$ \\
\cline { 2 - 4 } & $20 \%$ & 2218 & Moderate \\
\hline
\end{tabular}

\section{E. Effect of Marble Powder on Water Absorption}

The percentage water absorption for conventional and marble powder mixed concrete cubes is presented in Table $\mathrm{V}$. It was observed that there is no significant difference between the conventional concrete cubes and marble powder mixed concrete cubes.

Table V. Water Absorption Test Results

\begin{tabular}{|c|c|c|}
\hline Nature of specimen & $\begin{array}{c}\text { Volume fraction } \\
\text { In percentage }\end{array}$ & Water absorption \\
\hline \multirow{5}{*}{ Cube } & 0 & 1.56 \\
\cline { 2 - 3 } & 5 & 1.08 \\
\cline { 2 - 3 } & 10 & 1.21 \\
\cline { 2 - 3 } & 15 & 1.33 \\
\hline
\end{tabular}

\section{F. Effect of Marble Powder on Acid Resistance}

After immersion for 15 days in acid, the loss in weight and loss in compressive strength of conventional and marble powder mixed concrete specimens obtained and presented. It was observed that with the addition of marble powder there is no percentage of loss in weight. The loss in compressive strength was more in comparison with conventional concrete.

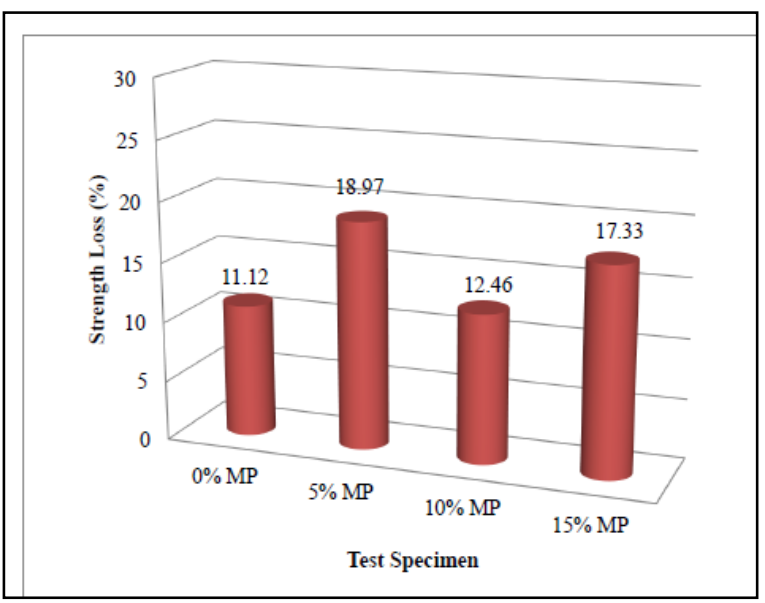

Fig. 5 Comparison of Compressive Strength after Acid Attack

\section{CONCLUSION}

- The compressive strength of cubes are increased with the addition of waste marble powder up to $10 \%$ replacement by weight of cement and further any addition of waste marble powder the compressive strength decreases.

- The addition of marble dust powder (10\% by weight of cement) into the concrete improved its compressive strength by $23.24 \%$ when compared with controlled specimen. 


\section{An Experimental Examination on Mechanical and Durability Properties of Cement Replacing with Marble}

Powder

- The flexural strength of cubes are increased with addition of waste marble powder up to $10 \%$ replacement by weight of cement and further any addition of waste marble powder the flexural strength decreases.

- The addition of marble dust powder (10\% by weight of cement) into the concrete improved its flexural strength by $17.82 \%$ when compared with controlled specimen.

- The marble powder can be used as a replacement material of cement and $10 \%$ replacement of cement with marble powder gives an excellent result in strength when compared to the normal concrete.

- Use of these waste material leads to sustainable development in construction industry

\section{ACKNOWLEDGEMENT}

Our sincere thanks to management of Sona College of technology Salem for giving consistent support for conducting experiments and special thanks to my doctoral committee members for their encouragement

\section{REFERENCES}

1. Ali Ergun (2011), Effects of The Usage of Diatomite and Waste Marble Powder as Partial Replacement of Cement on The Mechanical Properties of Concrete, Construction and Building Materials, Vol.25(3), pp.806-812.

2. 2.Ali Aliadbo, AbdElmoaty, M. and EsraaAuda, M. (2014), Re -Use of Waste Marble Dust in the Production of Cement and Concrete, Construction and Building Materials, Vol.50(4), pp.28-41.

3. Dixit S, Nigam S. and Bharosh R.,(2018) Strength and Durability of Concrete Made with Marble Dust, International Journal of Advance Research, Ideas And Innovations in Technology, Vol. 4, No. 2, pp. 464-470..

4. IS 10262:2009, Concrete Mix Proportioning - Guidelines, Bureau of Indian Standard (BIS), New Delhi, India.

5. IS 516-1959, Method of Test for Strength of Concrete, Bureau of Indian Standard, New Delhi, India.

6. IS 383-1970, Specifications for Coarse and Fine Aggregate from Natural Sources for Concrete, Bureau of Indian Standard, New Delhi, India.

7. Jashandeep singh and Bansal, R.S. (2015), Partial Replacement of Cement with Waste Marble Powder with M25 Grade, International Journal of Technical Research and Applications, Vol.3(2), 23242329

8. 8.KirtiVardhan, ShwetaGoyal, RafatSiddique and Malkit Singh (2015), Mechanical Properties and Micro Structural Analysis of Cement Mortar Incorporating Marble Powder as Partial Replacement of Cement, Construction and Building Material, Vol.96(5), pp.615-621.

9. Li L.G., Huang Z.H., Tan Y.P., Kwan A.K.H. and F. Liu,(2018) Use of marble dust as paste replacement for recycling waste and improving durability and dimensional stability of mortar, Construction and Building Materials, Vol. 166, pp. 423-432.

10. Li L.G, Wang Y.M., Tan Y.P, Kwan A.K.H. and Li L.J.(2018), Adding granite dust as paste replacement to improve durability and dimensional stability of mortar, Powder Technology, Vol. 333, pp. 269-276.

11. Pathan V. G. and Pathan M. G., Feasibility and Need of use of Waste Marble Powder in Concrete Production., IOSR Journal of Mechanical and Civil Engineering, pp. 23-26, 2014.

12. RamyaRaju, GeethaJayaraj, K. and Abuzar Aftab Shaikh (2014), Study of Partial Replacemet by Marble Powder, International Journal of Recent Advances in Engineering \& Technology, Vol.4(4)

13. Ranjan Kumar and Shyam Kishor Kumar (2015), Partial Replacement of Cement with Marble Dust Powder, International Journal of Engineering Research and Applications, Vol.5(8)pp.2248- 2254
14. Rohan, K., RoshanRai, Bhavani Shankar and Akshay, NK. (2014), Influence of Marble Dust as Partial Replacement of Cement in Normal Curing Concrete, Vol.2 (4) pp. 2278- 2284

15.

16. 15 Shirule, P.A., AtaurRahman and RakeshGupta, D. (2012), Partial Replacement of Cement with Marble Dust Powder, International Journal of Advanced Engineering Research and Studies, Vol.1(3), pp.175-177.

17. 16.Singh G. and Madan S. K.,(2018) An Experimental investigation on utilizations of Marble Dust as partial replacement of Cement in Concrete, New Building Materials \& Construction World, Vol. 23, No. 11, pp. 151-160.

18. Valeria Corinaldesi, Giacomo Moriconi and TarunNalik, R. (2010), Characterization of Marble Powder for its Use in Mortar and Concrete, Construction and Building Materials, Vol.24(6), pp.113-117.

19. Yang Zhong, Zhao Hui, Sun Wei,(2014), "Effect of the Type of Super plasticizers on the Fresh Mechanical and Durability properties of the High Performance Concrete", Crossref, Volume 44 issue 1, ISSN 0090-3973.

\section{AUTHORS PROFILE}

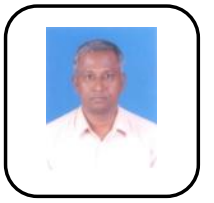

Dr. S. Suresh obtained his bachelor degree from M.K University, Madurai in the year 1992 and obtained his master degree from College of Engineering, Guindy, Chennai in the year 1996. With innovative thinking in research he joined as full time research scholar with UGC fellowship at Department of Civil Engineering, Indian Institute of science, Bangalore in the year 1997 and obtained his final graduation Ph.D in the year 2004. Dr S. Suresh has more than 20 years of teaching experience and published 23 International Journal papers and 26 International conference papers to his credit. At present he is guiding three $\mathrm{Ph} . \mathrm{D}$ research scholars at Anna University, Chennai and now he is working as professor, Department of Civil Engineering, Sona College of Technology, Salem-5. Dr. S. Suresh is a life member in Indian Society for Technical education (ISTE) and Life member in Indian Water Works Association.

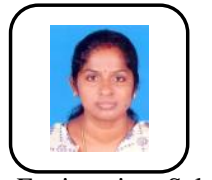

J.Revathi received her B.E, Degree in the year 2006 at Annamalai University, M.E degree at Annamalai University, Chidambaram in the year 2008. Presently she is working as a Assistant Professor at Ganesh College of Engineering, Salem in the department of civil Engineering 